\title{
KEMAMPUAN BERPIDATO SECARA EKSTEMPORAN SISWA KELAS IX SMP NEGERI 22 BENGKULU UTARA SEMESTER GENAP TAHUN AJARAN 2016/2017
}

\author{
Ferditia Karna Juwana ${ }^{1}$, Suhartono ${ }^{2}$, dan Agus Joko Purwadi ${ }^{3}$ \\ ${ }^{1,2,3}$ Program Studi Pendidikan Bahasa dan Sastra Indonesia \\ Jurusan Pendidikan Bahasa dan Seni \\ FKIP Universitas Bengkulu \\ Ferdytia karna@yahoo.com
}

\begin{abstract}
Abstrak
Tujuan Penelitian ini untuk mendeskripsikan kemampuan berpidato secara ekstemporan siswa kelas IX SMP Negeri 22 SMPN Bengkulu Utara semester genap Tahun Ajaran 2016/2017. Kemampuan berpidato secara ekstemporan siswa kelas IX ini akan dinilai dari lima aspek, yaitu: ketepatan ucapan dan pelafalan, kelancaran dan intonasi, diksi, sikap dan mimik/pandang muka, dan penguasaan bahasa. Metode yang digunakan adalah deskriptif dengan pendekatan kuantitatif. Dalam mencari sampel menggunakan teknik random sampling(sampel acak) yang diambil sebanyak $20 \%$ atau 20 orang siswa dari jumlah seluruh siswa 112 orang siswa, yang dipilih dari setiap kelasnya, yaitu 5 kelas. Sehingga sampel ada 5 kelas, teknik analisis data yang digunakan dalam penelitian yaitu statistik sederhana menghitung nilai rata-rata dari setiap aspek kebahasaan dan non kebahasaan serta mencari skor akhir.Hasil penelitian ini dapat dikemukakan bahwa: 1). Rata-rata kemampuan berpidato siswa yang dilihat dari aspek ketepatan ucapan dan pelafalanadalah 16,5 berkategori (baik). 2). Rata-rata Kemampuan Berpidato siswa dari aspek kelancaran dan intonasi adalah 16 berkategori (baik). 3). Rata-rata kemampuan berpidato siswa dari aspek diksi adalah 15,82 berkategori (baik). 4). Rata-ratakemampuan berpidato siswa dari aspek sikap dan mimik/pandang muka adalah 15,47 berkategori (baik). 5). Rata-rata kemampuan berpidato siswa dari aspek penguasaan bahasa adalah 15,55 berkategori (baik). 6). Rata rata nilai akhir kemampuan berpidato secara ekstemporan siswa kelas IX Smp Negeri 22 Bengkulu Utara Tahun Semester Genap Ajaran 2016/2017 adalah 79,37 tergolong berkategori(baik).Kesimpulan dari penelitian ini adalah bahwa siswakelas IX di SMP Negeri 22 Bengkulu Utara Semester Genap Tahun Ajaran 2016/2017 telah dapat berpidato secara ekstemporan dengan baik. Meskipun masih ada beberapa siswa dalam berpidato secara ekstemporan dinyatakan cukup, namun secara keseluruhan para siswa sudah dapat berpidato secara ekstemporan dengan baik.
\end{abstract}

Kata kunci: kemampuan, berpidato, metode ekstemporan

\begin{abstract}
The purpose of this study is to describe the ability of speech in extemporan students of class IX SMP Negeri 22 SMPN Bengkulu Utara even semester of the academic year 2016/2017. The ability to speak in an extension of the class IX students will be assessed from five aspects, namely: the accuracy of speech and pronunciation, fluency and intonation, diction, attitude and expression / face, and language mastery. The method used is descriptive with quantitative approach. In searching the sample using random sampling technique (random sample) taken as much as $20 \%$ or 20 students from the total student of 112 students. Data analysis techniques used in the study of simple statistics calculate the average value of every aspect of language and non linguistic and look for final score. The results of this study can be
\end{abstract}


stated that: 1). The average of students' speech abilities viewed from the aspect of the accuracy of speech and pronunciation is 16.5 categorized (good). 2). Average Ability of Student Speech from the aspect of smoothness and intonation is 16 categorized (good). 3). The average student's speech ability from the diction aspect is 15.82 (good). 4). The average student's speech ability from attitude and facial / face-to-face aspects is 15.47 categorized (good). 5). The average student's speech ability from the language mastery aspect is 15.55 categorized (good). 6). The average final score of speech extension ability of the students of class IX of SmpNegeri 22 North Bengkulu Year Even Semester of Teaching 2016/2017 is 79.37 is categorized (good). The conclusion of this research is that the students of class IX in State Junior High School 22 North Bengkulu Even Semester of Academic Year 2016/2017 has been able to speech by extemporan well. Although there are still some students in extension speeches is sufficient, but overall the students have been able to speak in exemporan well.

\section{Keywords: ability, speech, extemporane methode}

\section{PENDAHULUAN}

Pidato adalah sebuah kegiatan berbicara di depan umum atau berorasi untuk menyatakan pendapatnya, atau memberikan gambaran tentang suatu hal. Pidato biasanya dibawakan oleh seorang yang memberikan orasi-orasi, dan pernyataan tentang suatu hal atau peristiwa yang penting dan patut diperbincangkan. Pembelajaran berpidato adalah sebagian dari pembelajaran bahasa Indonesia dan merupakan suatu proses pembelajaran antara guru dan siswa, yang menjadikan proses pengenalan, pemahaman, dan penghayatan. Pada akhirnya akan bisa mampu menerapkannya pada kehidupan sehari-hari. Pembelajaran berpidato juga dalam kegiatan belajar mengajar harus diupayakan secara maksimal agar bisa bisa tercipta suasana belajar mengajar yang menyenangkan.

Putri (2010:11) pidato adalah sebuah kegiatan berbicara di depan umum atau bisa dikatakan sebagai public speaking. Tomi (2002:1) mengemukakan bahwa berbicara sangat penting dimiliki seseorang agar tidak terjadi kesalah pahaman antara penutur dan lawan tutur dalam berkomunikasi. Bentuk komuniskasi lisan ini paling banyak digunakan orang dalam kehidupan sehari hari karena bentuk komunikasi verbal dianggap paling sempurna, efesien dan efektif. Menurut Jalaluddin (2009:78) pidato adalah komunikasi tatap muka, yang bersifat dua arah, yakni pembicara harus memperhatikan lawan bicaranya, walaupun pembicara lebih banyak mendominasi pembicaraan. Taraf kemampuan berpidato, menyatakan maksud dan perasaan secara lisan pada tiap-tiap siswa tidaklah sama. Kemampuan tersebut bervariasi, mulai dari taraf baik atau lancar, sedang, gagap atau kurang.

Ntelu (2013:180) pidato merupakan salah satu ragam berbicara yang digunakan dalam forum-forum. Seseorang yang akan berpidato di depan khalayak, memiliki kemampuan berbicara untuk menyampaikan ide, gagasan, pikiran dan perasaannya kepada orang lain dengan baik.

Salah satu materi pembelajaran bahasa Indonesia di tingkat SMP yang terdapat dalam Kurikulum 2013 khususnya kelas IX, dinyatakan siswa mampu mengungkapkan pikiran, perasaan, dan informasi dalam berpidato dengan intonasi yang tepat, artikulasi, dan volume suara yang jelas.

Pemilihan SMP Negeri 22 Bengkulu Utara sebagai tempat penelitian di dasari atas pertimbangan, yaitu (1) SMP Negeri 22 Bengkulu Utara khususnya siswa kelas 
IX telah mendapat pembelajaran berpidato sesuai dengan kurikulum 2013, (2) SMP Negeri 22 Bengkulu Utara merupakan salah satu Sekolah Standar Nasional (SSN) sehingga seluruh perangkat sekolah khususnya siswa harus memiliki kecakapan.

\section{METODE}

Penelitian ini menggunakan pendekatan kuantitatif dengan metode deskriptif. Tempat penelitian dilakukan di kelas IX SMP Negeri 22 Bengkulu Utara dari kelas IX A, IX B, IX C, IX, D dan IX E. Sumber data dalam penelitian ini yakni Arwanudin, S.Pd. selaku guru bahasa Indonesia di kelas IX A dan IX B,IX B, IX C, IX, D dan IX E serta peserta didik yang berjumlah 112 siswa dari kelas IX A dan IX B, IX B, IX C, IX, D dan IX E .Teknik yang digunakan dalam pengumpulan data yaitu teknik tes lisan.

\section{HASIL DAN PEMBAHASAN}

Berdasarkan hasil penelitian yang sudah dilakukan maka diperoleh hasil penelitian terdiri atas 5 aspek sebagai berikut.

\begin{tabular}{|c|c|c|c|}
\hline No. & Aspek Yang Dinilai & $\begin{array}{l}\text { Rata-rata } \\
\text { Nilai Skor }\end{array}$ & Kategori \\
\hline 1. & $\begin{array}{l}\text { Ketepatan } \\
\text { Ucapan/Pelafalan }\end{array}$ & 16,5 & $\begin{array}{l}\text { Sangat } \\
\text { Baik }\end{array}$ \\
\hline 2. & $\begin{array}{l}\text { Kelancaran dan } \\
\text { Intonasi }\end{array}$ & 16,05 & Baik \\
\hline 3. & Diksi & 15,82 & Baik \\
\hline 4. & $\begin{array}{l}\text { Sikap dan } \\
\text { Mimik/Pandang } \\
\text { Muka }\end{array}$ & 15,47 & Baik \\
\hline 5. & $\begin{array}{l}\text { Penguasaan } \\
\text { Bahasa }\end{array}$ & 15,55 & Baik \\
\hline 6. & Keseluruhan & 79,37 & Baik \\
\hline
\end{tabular}

Berdasarkan hasil perhitungan pada tabel, dapat diperoleh skor akhir kemampuan berpidato secara ekstemporan siswa ialah 79,37, sehingga jika dimasukkan dalam rentang skor skala lima dapat dikatakan bahwa kemampuan berpidato secara ekstemporan siswa kelas
IX SMP Negeri 22 Bengkulu Utara Tahun Ajaran 2016/2017 dapat dikategorikan baik.

Berdasarkan hasil penelitian data, kemampuan berpidato secara ekstemporan siswa dari seluruh aspek berpidato siswa Kelas IX SMP Negeri 22 Bengkulu Utara Semester Genap Tahun Ajaran 2016/2017 dikategorikan baik. Nilai skor akhir yang diperoleh sebesar $79,37 \%$. Hasil ini sesuai dengan teori pendapat Nurgiyantoro (1988:364) bahwa rentang skor 75-84 berkategori baik.

Kemampuan Berpidato secara Ekstemporan Siswa dari Aspek Ketepatan Ucapan dan Pelafalan.

Berdasarkan hasil analisis data yang telah dilakukan pada Kemampuan Berpidato siswa Kelas IX SMP Negeri 22 Bengkulu Utara semester genap Tahun Ajaran 2016/2017, sudah dapat berpidato dengan baik.

Berdasarkan hasil analisis data, kemampuan berpidato secara ekstemporan siswa kelas IX SMP Negeri 22 Bengkulu Utara semester genap tahun ajaran 2016/2017.

Dalam Aspek ketepatan ucapan dan pelafalan dikategorikan sangat baik karena rata-rata yang diperoleh sebesar 16,5. Hasil ini sesuai dengan rentang teori rentang skor antara 17-20 berkategori sangat baik.

Selain itu, dari hasil analisis data yang telah dilakukan pada aspek ketepatan ucapan dan pelafalan, kebanyakan siswa sudah dapat berpidato dengan baik. Sesuai dengan kategori penilaian dalam aspek ketepatan ucapan dan pelafalan, seperti sesekali terjadi kekurang tepatan Ucapan namun Pelafalan ucapan sudah baik. Hanya saja ada beberapa siswa yang Terjadi kekurang tepatan ucapan dan kesalahan Pelafalan cukup terjadi berulang-ulang. 
Kemampuan Berpidato Secara Ekstemporan Siswa dari Aspek Kelancaran dan Intonasi.

Berdasarkan hasil penelitian data, kemampuan berpidatosecara ekstemporan siswa kelas IX SMP Negeri 22 Bengkulu Utara. Dalam aspek kelancaran dan intonasi dikategorikan baik karena ratarata yang diperoleh sebesar 16 . Hasil ini sesuai dengan teori rentang skor antara 1316 berkategori baik.

Selain itu, dari hasil analisis data yang telah dilakukan pada aspek Kelancaran dan Intonasi kebanyakan siswa sudah dapat berpidato dengan baik. Sesuai dengan kategori penilaian dalam aspek kelancaran dan Intonasi, seperti Suara lancar sejak awal sampai akhir, Intonasi jeda baik serta pelafalan ucapan sudah baik. Hanya saja ada beberapa siswa yang Suara agak tersendat namun masih lancar, intonasi cukup tepat.

\section{Kemampuan Berpidato Secara Ekstemporan Siswa dari Aspek Diksi.}

Berdasarkan hasil analisis data, kemampuan berpidato secara ekstemporan siswa kelas IX SMP Negeri 22 Bengkulu Utara semester genap tahun ajaran 2016/2017. Dalam aspek diksi dikategorikan baik karena rata-rata nilai yang diperoleh sebesar 15,8. Hasil ini sesuai dengan teori rentang skor antara 1316 berkategori baik.

Selain itu, dari hasil analisis data yang telah dilakukan pada aspek diksi, kebanyakan siswa sudah dapat berpidato dengan baik. Sesuai dengan kategori penilaian dalam aspek diksi, seperti pilihan diksi yang digunakanbaik. Hanya saja ada beberapa siswa yang Terjadi pilihan diksi yang digunakan cukup tepat.

\footnotetext{
Kemampuan Berpidato Secara Ekstemporan Siswa dari Aspek Sikap Gerak-gerik dan Mimik/Pandang Muka.
}

Berdasarkan hasil analisis data,
kemampuan berpidato secara ekstemporan siswa kelas IX SMP Negeri 22 Bengkulu Utara semester genap tahun ajaran 2016/2017. Dalam aspek sikap dan mimik/pandang muka dikategorikan baik karena rata-rata yang diperoleh sebesar 15,4 . Hasil ini sesuai dengan teori rentang skor antara $13-16$ berkategori baik.

Selain itu, dari hasil analisis data yang telah dilakukan pada aspek Sikap dan Mimik/PandangMuka, kebanyakan siswa sudah dapat berpidato dengan baik. Sesuai dengan kategori penilaian dalam aspek Sikap dan mimik/pandang muka, seperti Sesekali terjadi Gerakan Sikap dan mimik wajah komunikatif namun agak sesuai baik. Hanya saja ada beberapa siswa yang Terjadi Gerakan Sikap dan mimik wajah kurang komunikatif serta kurang sesuai.

\section{Kemampuan Berpidato Secara Ekstemporan Siswa dari Aspek Penguasaan Bahasa.}

Berdasarkan hasil analisis data, kemampuan berpidato secara ekstemporan siswa kelas IX SMP Negeri 22 Bengkulu Utara semester genap tahun ajaran 2016/2017. Dalam aspek penguasaan bahasa dikategorikan sudah baik karena rata-rata yang diperoleh sebesar 15,55 . Hasil ini sesuai dengan teori rentang skor 13-16 berkategori baik.

Selain itu, dari hasil analisis data yang telah dilakukan pada aspek Penguasaan Bahasa, kebanyakan siswa sudah dapat berpidato dengan baik. Sesuai dengan kategori penilaian dalam aspek ketepatan ucapan dan pelafalan, Penguasaan bahasa yang digunakan sudah tepat namun terpengaruh dialek daerah. Pada gerakan sikap dan pandang muka sudah banyak yang melakukan gerakan komunikatif. Hanya saja ada beberapa siswa yang Terjadi Penguasaan bahasa yang digunakan sudah cukup baik 


\section{PENUTUP}

\section{Kesimpulan}

Berdasarkan hasil penelitian dan pembahasan dapat disimpulkan bahwa kemampuan berpidato secara ekstemporan siswa kelas IX SMP Negeri 22 Bengkulu Utara Semester genap tahun ajaran 2016/2017 berkategori baik.

Hal ini dapat dilihat dari hasil perhitungan rata- rata nilai sebesar 79,37\%. Hal ini berarti kemampuan berpidato secara ekstemporan siswa kelas IX SMP Negeri 22 Bengkulu Utara Semester genap tahun ajaran 2016/2017 berkategori baik. Hal ini membuktikan bahwa berpidato merupakan sebuah keterampilan yang dapat dipelajari dan dikembangkan. Artinya kepandaian berpidato diperoleh bukan melalui bakat alami, tetapi bisa pula didapat melalui keseriusan pembelajaran paktek dan proses latihan yang intensif.

\section{Saran}

Penelitian tentang kemampuan berpidato secara ekstemporan siswa kelas IX SMP Negeri 22 Bengkulu Utara semester genap tahun ajaran 2016/2017, diharapkandapat memberikan masukkan saran kepada.

1. Guru khususnya guru bahasa Indonesia disarankan dalam menentukan model pembelajaran kemampuan berpidato yang membaca pidatonya dikembangkan dengan kreatif dan yang baik oleh siswanya.
2. Siswa disarankan banyak berlatih dalam berpidato dengan menggunakan metode ekstemporan dan bila perlu mencoba metode pidato yang lain agar semakin mahir dalam berpidato.

3. Pihak sekolah merupakan masukan yang berupa saran atau kritik yang membangun terhadap guru-guru dalam melaksanakan proses pembelajaran terhadap peserta didiknya.

\section{DAFTAR PUSTAKA}

Jalaluddin, Rakhmat. 2009. Retorika Modern Pendekatan Praktis. Bandung: PT Remaja Rosdakarya.

Ntelu, Asna dkk. 2013. Bahasa Indonesia di Perguruan Tinggi. Gorontalo: Ideas Publising.

Nurgiyantoro, Burhan. 1987. Penilaian dalam Pengajaran Bahasa dan Sastra Indonesia. Yogyakarta: BPFE.

Putri, Pandan Wangi. 2010. Bukan Pidato Biasa. Klaten: One Books.

Tomi,Yuniawan. 2002. Paparan Perkuliahan Retorika. Semarang: FBS Unnes. 